Research Paper: Autophagy and Cell Death

\title{
Analysis of the immune microenvironment in resected non-small cell lung cancer: the prognostic value of different $T$ lymphocyte markers
}

\author{
Marta Usó ${ }^{1,2, *}$, Eloisa Jantus-Lewintre ${ }^{2,3, *}$, Roy M. Bremnes ${ }^{4,5}$, Silvia Calabuig ${ }^{2,6}$, Ana \\ Blasco7, Enrique Pastor ${ }^{8}$, Irene Borreda ${ }^{9}$, Sonia Molina-Pinelo ${ }^{10}$, Luis Paz-Ares ${ }^{10,11}$, \\ Ricardo Guijarro ${ }^{8}$, Miguel Martorell12, Jerónimo Forteza9 ${ }^{12}$ Carlos Camps ${ }^{1,2,7}$ and \\ Rafael Sirera ${ }^{3}$ \\ ${ }^{1}$ Department of Medicine, Universitat de València, Valencia, Spain \\ ${ }^{2}$ Molecular Oncology Laboratory, Fundación Investigación, Hospital General Universitario de Valencia, Valencia, Spain \\ ${ }^{3}$ Department of Biotechnology, Universitat Politècnica de València, Valencia, Spain \\ ${ }^{4}$ Department of Oncology, University Hospital of North Norway, Tromso, Norway \\ ${ }^{5}$ Department of Clinical Medicine, The Arctic University of Norway, Tromso, Norway \\ ${ }^{6}$ Department of Pathology, Universitat de València, Valencia, Spain \\ ${ }^{7}$ Medical Oncology Department, Hospital General Universitario de Valencia, Valencia, Spain \\ ${ }^{8}$ Department of Thoracic Surgery, Hospital General Universitario de Valencia, Valencia, Spain \\ 9 Instituto Valenciano de Patología, Universidad Católica de Valencia, Unidad Mixta de Patología Molecular Centro de \\ Investigación Príncipe Felipe (CIPF)-Universidad Católica de Valencia (UCV), Valencia, Spain \\ ${ }^{10}$ Medical Oncology Department, Hospital 12 de Octubre \& Centro Nacional de Investigaciones Oncológicas (CNIO), Madrid, \\ Spain \\ ${ }^{11}$ Universidad Complutense de Madrid, Madrid, Spain \\ 12 Department of Pathology, Hospital General Universitario de Valencia, Valencia, Spain \\ * These authros have contributed equally to this work \\ Correspondence to: Rafael Sirera, email: rsirera@btc.upv.es
}

Carlos Camps, email: camps_car@gva.es

Keywords:NSCLC, prognostic, immune-biomarker, tumor stroma, tumor compartment

Received: March 14, $2016 \quad$ Accepted: July 15, $2016 \quad$ Published: July 24, 2016

\section{ABSTRACT}

The prognosis of non-small cell lung cancer (NSCLC) remains poor and heterogeneous and new biomarkers are needed. As the immune system plays a pivotal role in cancer, the study of immune-related markers may provide valuable prognostic information of NSCLC. In 122 formalin-fixed, paraffin-embedded tumor tissue samples from early-stage NSCLC, tumor and tumor-near stromal areas were microdissected and gene expression levels of conventional and regulatory $\mathrm{T}$ cell markers were assessed by quantitative polymerase chain reaction. Also, the presence of infiltrating CD4+, CD8+, and FOXP3+ cells in tumor samples was assessed by immunohistochemistry. The relative proportion of conventional and regulatory $T$ cells present in the tumor environment was assessed and found to be key to understand the importance that the immune system analysis has in the prognostics of NSCLC patients. The presence of CD8+ cells in the tumor compartment was associated with better outcome, whereas the presence of FOXP3+ cells was associated with worse overall survival. The negative prognostic value of combined biomarkers, indicating high levels of FOXP3 in the stroma and low levels of CD4 or CD8 in tumors, was observed at mRNA level and was validated by immunohistochemistry.In conclusion, the proportion of $T$ helper and cytotoxic cells vs. regulatory $T$ cells in different locations of the tumor microenvironment have opposite prognostic impacts in resected NSCLC. 


\section{INTRODUCTION}

Lung cancer is the leading cause of cancer-related death worldwide [1]. Five-year survival remains poor, mainly due to late debut of symptoms and the presence of regional or distant metastases at diagnosis [2]. An increasing research effort has been invested in order to detect and validate novel biomarkers in non-small cell lung cancer (NSCLC). Although some of these markers have been adopted in current clinical practice, several potential biomarkers have not yet been adequately validated $[3,4]$. Both tumor-preventing and tumor-promoting inflammation has been proved to play prognostic roles in several solid tumors [5-8]. Tumor-infiltrating cytotoxic T cells are of crucial importance in suppressing cancer development and controlling disease progression. Among the different cell subsets of tumor infiltrating lymphocytes (TILs), the most promising biomarker so far are $\mathrm{CD} 8+$ cytotoxic $\mathrm{T}$ lymphocytes, that are a pivotal component of the cellmediated antitumor immune responses [9]. In NSCLC, together with other malignancies, many studies have evaluated the clinical value of CD8+ cells alone or combined with other biomarkers, demonstrating a strong independent positive prognostic effect regardless of tissue compartments evaluated [10-16].

On the other hand, regulatory $\mathrm{T}$ cells (Tregs) are a subtype of $\mathrm{CD} 4+\mathrm{T}$ cells with immunosuppressive properties that express high levels of CD25 and low levels of CD127 on their cell surface $[17,18]$. One of the most reliable phenotypic markers for Tregs is FOXP3, which is essential for their development and function and which has been broadly used for their detection [19]. Tregs are also characterized by the expression of other markers such as cytotoxic T-lymphocyte-associated antigen 4 (CTLA4), lymphocyte activation gene 3 (LAG3) and glucocorticoid induced tumor necrosis factor receptor family related gene (GITR), or soluble immunosuppressive factors such as interleukin 10 (IL10) and transforming growth factor beta 1 (TGBF1) [20]. The presence of FOXP3+ lymphocytes in cohorts of patients affected by different types of tumors, has been associated with a poor prognosis [21-25] or a better locoregional control and prognosis [26-29].

Altogether, the data obtained so far indicates that immune system-related biomarkers, and more specifically those involved in immunoregulation, may become useful in both development of the next generation biomarkers in NSCLC and as potential targets for novel therapies. Furthermore, it should be taken into consideration that the prognostic and predictive value of a given biomarker may be different or even opposite depending on which cellular compartment of the tumor it is expressed. Therefore, further studies using feasible and reliable techniques such as quantitative real-time PCR (RTqPCR), based on microdissected specimen, or immunohistochemistry (IHC) are essential to detect and validate new biomarkers. The aim of this study was to analyze the presence of immune markers at the mRNA and protein level in the tumor and tumor-near stroma compartment separately, and to investigate the relative proportion of conventional and regulatory $\mathrm{T}$ cells present in the tumor surrounding in order to understand their associations with the patients' prognosis in an unselected cohort of resected NSCLC patients.

\section{RESULTS}

\section{Patient characteristics}

Detailed clinical and pathological information including age, gender, stage of disease and histology are summarized in Table 1. The median follow-up was 53.3 [1-113] months. Of the 122 resected NSCLC patients included, 68 (55.7\%) relapsed and 67 (54.9\%) died during the follow-up period.

\section{Relative gene expression}

All of the analyzed genes could be amplified using the selected primers/probes. We observed a strong overexpression, in both the tumor-near stroma and the tumor (measured as fold-change, $\mathrm{X}$ and range) of CD25 (19.46X, [2.7-86.0], 11.59X, [0.3-54.2]), FOXP3 (4.96X, [0.2-67.4], 4.08X, [0.1-38.0]), CTLA4 (2.89X, [0.2-65.7], $3.02 \mathrm{X},[0.1-59.8])$ and TGFB1 (3.24X, [0.6-16-6], 2.117X, [0.2-27.2]). In contrast, IL10 expression in the tumor compartment was downregulated (0.39X, [0.02-40.3]).

\section{CD4+, CD8+, and FOXP3+ cell infiltration}

In tonsil tissue samples, positive staining for CD4 and CD8 was observed in the cytoplasm of lymphocytes, whereas FOXP3 staining was observed in the nucleus; the same pattern was seen in patient samples. There was no positive staining in the negative controls. Figure 1 shows a representative immunohistochemical staining of FOXP3, CD4 and CD8 in tumor and stroma compartments. CD4+ and $\mathrm{CD} 8+$ cells were detected in all assessable samples, although in $13(15.5 \%)$ of the 84 samples CD4+ cells were only found in the tumor-near stromal compartment. FOXP3 + cells were detected in $80(95.2 \%)$ of the 84 assessable samples, although in $8(10 \%)$ positive cells were only found in the tumor-near stromal compartment, and in one case $(1.8 \%)$ positive cells were only found in the tumor compartment. For the three markers, there were significantly more positive $\mathrm{T}$ cells in the tumornear stroma than in the tumor compartment (pair-wise Wilcoxon test, $p<0.001$ ). The number of positive cells 
Table 1: Clinicopathological characteristics of the patients.

\begin{tabular}{|c|c|c|}
\hline Characteristics & $\mathbf{N}$ & $\%$ \\
\hline $\begin{array}{l}\text { Age at surgery } \\
\text { (median, range) }\end{array}$ & \multicolumn{2}{|c|}{65 [26-85] } \\
\hline \multicolumn{3}{|l|}{ Gender } \\
\hline Male & 104 & 85.4 \\
\hline Female & 18 & 14.6 \\
\hline \multicolumn{3}{|l|}{ Stage } \\
\hline $\mathrm{I}$ & 72 & 59 \\
\hline II & 26 & 21.3 \\
\hline IIIA & 24 & 19.7 \\
\hline \multicolumn{3}{|l|}{ Histology } \\
\hline $\mathrm{SCC}$ & 58 & 47.5 \\
\hline $\mathrm{ADC}$ & 51 & 41.8 \\
\hline Others & 13 & 10.7 \\
\hline \multicolumn{3}{|l|}{ Performance Status } \\
\hline 0 & 70 & 57.4 \\
\hline $1-2$ & 35 & 28.7 \\
\hline $\mathrm{NS}$ & 17 & 13.9 \\
\hline \multicolumn{3}{|l|}{$\begin{array}{l}\text { Differentiation } \\
\text { grade }\end{array}$} \\
\hline Poor & 29 & 23.8 \\
\hline Moderate & 48 & 39.3 \\
\hline Well & 28 & 23 \\
\hline $\mathrm{NS}$ & 17 & 13.9 \\
\hline \multicolumn{3}{|l|}{ Smoking Status } \\
\hline Current & 59 & 48.4 \\
\hline Former & 46 & 37.7 \\
\hline Never-smoker & 17 & 13.9 \\
\hline \multicolumn{3}{|l|}{ EGFR } \\
\hline Wild type & 43 & 35.2 \\
\hline Mutated & 9 & 7.4 \\
\hline NA & 70 & 57.4 \\
\hline \multicolumn{3}{|l|}{ KRAS } \\
\hline Wild type & 83 & 68 \\
\hline Mutated & 14 & 11.5 \\
\hline NA & 25 & 20.5 \\
\hline
\end{tabular}

ADC, adenocarcinoma; SCC, squamous; NA; not analyzed; NS, non-specified; EGFR, epidermal growth factor receptor.

per HPF in the stromal compartment ranged from 1 to 76 (median: 18.8) for CD4, from 3 to 73 (median: 29.8, mean: 29) for CD8 and from 0 to 45 (median: 11.6) for FOXP3. On the other hand, in the tumor compartment the number ranged from 0 to 21 (median: 1.8 , mean: 3.5 ) for CD4, from 1 to 82 (median: 5.6) for CD8 and from 0 to 15 (median: 1, mean: 1.6) for FOXP3.

Patients' tumors were classified as being weakly to strongly infiltrated by CD4+ and CD8+ immune cells in tumor and tumor-near stroma compartments according to the median calculated for each marker. For FOXP3 expression in the stromal compartment, $6 \%$ of the samples were negative, 55\% expressed in less than $10 \%$ of lymphocytes, $38 \%$ between $10 \%$ and $33 \%$, and $1.2 \%$ in more than $33 \%$. For the tumor compartment, $14 \%$ were negative, $71 \%$ expressed in less than $10 \%$ positive lymphocytes, $13 \%$ in $10 \%$ and $33 \%$, and $1.2 \%$ in more than $33 \%$.

\section{Correlation with clinicopathological variables}

The expression, in both tumor and stromal compartments, of CD4 $(p=0.024$ and $p=0.008$, respectively), $\mathrm{CD} 8$ ( $p=0.044$ and $p=0.008$, respectively), and LAG3 ( $p=0.008$, in both cases) were higher in adenocarcinoma (ADC) than in squamous cells carcinoma (SCC) patients. Moreover, higher IL10 expression was found in patients with stage I than stage II/IIIA disease $(p=0.027)$. As for the correlations with positive cell infiltration, we observed that higher levels (above the median) of CD4+ cells in the tumor stroma correlated with epidermal growth factor receptor (EGFR)-mutated patients $(p=0.047)$ and with ADC histology $(p=0.030)$. Furthermore, smaller tumors (less than $3.5 \mathrm{~cm}$ ) were associated with a higher number of stromal CD8+ cells $(p=0.047)$.

\section{Prognostic value of gene expression markers and immune cell infiltration in tumor and tumor-near stroma}

Survival analyses indicated that patients with high CD4 expression in the tumor compartment, dichotomized according to the median of its relative expression, had improved PFS (37.8 vs. 23 months, $p=0.042$ ) and OS (81.2 vs. 42.9 months, $p=0.018$ ). Similarly, high levels of CD8 expression in the tumor compartment were associated with improved PFS (81.2 vs. 19.4 months, $p=0.001)$ and OS (81.2 vs. 37.2 months, $p<0.001)$. The expression of CD8 in the stroma was also correlated with OS (74.3 vs. 46.4 months, $p=0.032$ ). With respect to FOXP3 high expression levels were correlated with longer PFS (35.3 vs. 22.1 months, $p=0.020$ ) and OS (NR vs. 37.2 months, $p=0.005)$.. Moreover, patients with high expression levels of LAG3 presented a better OS (69 vs. 36.2 months, $p=$ 0.023 ), and the same was observed for TGFB1 (74.3 vs. 46.6 months, $p=0.032$; Table 2). Kaplan-Meier plots for all these biomarkers are shown in supplementary Figure 1.

As for the immune cells markers detected by IHC, the presence of CD8+ cells in the tumor compartment, according to the median of positive cells infiltrating the tumor, was significantly associated with better PFS (56.8 vs. 23 months, $p=0.026$ ) and OS (73.9 vs. 40.4 months, $p=0.021$; Figure 2A-2B), whereas patients with a higher percentage of FOXP3 + cells in the stromal compartment (more that $10 \%$ of positive lymphocytes) had shorter OS (37.2 vs. 68 months, $p=0.029$; Figure 2C-2D; Table 2). 
Table 2:Univariate analysis of the gene expression and immune cells infiltration-related biomarkers.

\begin{tabular}{|c|c|c|c|c|}
\hline \multirow{2}{*}{ Variable } & \multicolumn{2}{|l|}{$\mathbf{O S}$} & \multicolumn{2}{|l|}{ PFS } \\
\hline & $\begin{array}{l}\text { Median survival } \\
\text { (months) }\end{array}$ & $p$-value & $\begin{array}{l}\text { Median survival } \\
\text { (months) }\end{array}$ & $p$-value \\
\hline \multicolumn{5}{|l|}{ Gene expression markers $(N=122)$} \\
\hline $\begin{array}{l}\text { Tumoral CD4 } \\
\text { High vs. low }\end{array}$ & 81.2 vs. 42.9 & 0.018 & 37.8 vs. 23 & 0.042 \\
\hline $\begin{array}{l}\text { Tumoral CD } 8 \\
\text { High vs. low }\end{array}$ & 81.2 vs. 37.2 & $<0.001$ & 81.2 vs. 19.4 & 0.001 \\
\hline $\begin{array}{l}\text { Stromal CD8 } \\
\text { High vs. low }\end{array}$ & 74.3 vs. 46.4 & 0.032 & 29.1 vs. 25.6 & 0.237 \\
\hline $\begin{array}{l}\text { Tumoral FOXP3 } \\
\text { High vs. low }\end{array}$ & NR vs. 37.2 & 0.005 & 35.3 vs. 22.1 & 0.020 \\
\hline $\begin{array}{l}\text { Tumoral LAG3 } \\
\text { High vs. low }\end{array}$ & 69 vs. 36.2 & 0.023 & 30.1 vs. 22.1 & 0.107 \\
\hline $\begin{array}{l}\text { Tumoral TGBF1 } \\
\text { High vs. low }\end{array}$ & 74.3 vs. 46.6 & 0.032 & 31.5 vs. 22.1 & 0.174 \\
\hline $\begin{array}{l}\text { Ratio FOXP3stroma/ CD4tumor } \\
\text { High vs. low }\end{array}$ & 46.6 vs. 81.2 & 0.012 & 19.4 vs. 37.8 & 0.013 \\
\hline $\begin{array}{l}\text { Ratio FOXP3stroma/ CD8tumor } \\
\text { High vs. low }\end{array}$ & 46.4 vs. 74.3 & 0.025 & 23 vs. 37.8 & 0.042 \\
\hline \multicolumn{5}{|l|}{ Immune cells markers $(N=84)$} \\
\hline $\begin{array}{l}\text { Tumoral CD8 }{ }^{+} \text {cells } \\
\text { High vs .Low }\end{array}$ & 73.9 vs. 40.4 & 0.021 & 56.8 vs. 23 & 0.026 \\
\hline $\begin{array}{l}\text { Stromal FOXP3 } 3^{+} \text {cells } \\
\text { High vs. Low }\end{array}$ & 37.2 vs. 68 & 0.029 & 17.4 vs. 46.6 & 0.101 \\
\hline $\begin{array}{l}\mathrm{FOXP}^{+} \text {stroma/ } \mathrm{CD}^{+} \text {tumor } \\
\text { High vs. Low }\end{array}$ & 17.4 vs. 66.9 & 0.024 & 32.5 vs. 15.3 & 0.086 \\
\hline $\begin{array}{l}\mathrm{FOXP}^{+} \text {stroma/ } \mathrm{CD}^{+} \text {tumor } \\
\text { High vs. Low }\end{array}$ & 17.4 vs. 68.8 & 0.011 & 15.3 vs. 35.9 & 0.035 \\
\hline
\end{tabular}

NR, not-reached; OS, overall survival; PFS, progression free survival. The p-value was calculated using the log-rank test.

Table 3: Results from the multivariate Cox regression model for OS and PFS.

\begin{tabular}{|c|c|c|c|c|c|c|}
\hline & \multicolumn{3}{|l|}{ OS } & \multicolumn{3}{|l|}{ PFS } \\
\hline Variable & HR & $95 \%$ CI & $p$-value & HR & $95 \% \mathrm{CI}$ & $p$-value \\
\hline \multicolumn{7}{|c|}{ Gene expression markers $(N=122)$} \\
\hline $\begin{array}{l}\text { Tumoral CD8 expression } \\
\text { High vs. low }\end{array}$ & 0.169 & $0.064-0.447$ & $<0.001$ & 0.247 & $0.120-0.507$ & $<0.001$ \\
\hline \multicolumn{7}{|c|}{ Immune cells markers $(N=84)$} \\
\hline $\begin{array}{l}\text { Tumoral } \mathrm{CD}^{+} \text {cells } \\
\text { High vs. Low }\end{array}$ & 0.386 & $0.175-0.850$ & 0.018 & 0.305 & $0.137-0.680$ & 0.004 \\
\hline $\begin{array}{l}\text { Stromal FOXP3 }{ }^{+} \text {cells } \\
\text { High vs. Low }\end{array}$ & 2.203 & $1.109-4.379$ & 0.024 & - & - & - \\
\hline
\end{tabular}

CI, confidence interval; HR, hazard ratio; OS, overall survival; PFS, progression free survival. 


\section{Prognostic value of combined biomarkers}

According to these results, and taking into account the biological interactions between the immune cells that express these markers, we decided to further study the prognostic value of the combination of conventional $\mathrm{T}$ cells (CD4 and CD8) and Tregs (FOXP3). First, we calculated new variables based on the ratio of these markers and used the median to dichotomized them as "low" or "high". From the different combinations that were tested we observed that patients with a high FOXP3 stroma/ CD4 tumor expression ratio have reduced PFS (19.4 vs. 37.8 months, $p=0.013$ ) and OS (46.6 vs. 81.2 months, $p=0.012$; Figure 3A-3B; Table 2). As for the FOXP3 stroma/ CD8 tumor expression ratio, patients with high levels also presented worse PFS (23 vs. 37.8 months, $p=0.042)$ and OS (46.4 vs. 74.3 months, $p=0.025$; Figure 3C-3D; Table 2).

To validate these results, available tissue samples from 84 of the122 patients were also assessed by IHC. Univariate survival analyses showed that patients with high FOXP3 + cells infiltration (more than $10 \%$ of positive lymphocytes) in the stroma and low CD4+ cells infiltration in the tumor (according to the median of positive cells infiltrating in the tumor) presented significantly worse OS
(17.4 vs. 66.9 months, $p=0.024$; Figure 4A-4B; Table 2). Moreover, patients with high infiltration of FOXP3 + cells in the stroma and low infiltration of CD8+ in the tumor also presented inferior PFS (15.3 vs. 35.9 months, $p=$ $0.035)$ and $\mathrm{OS}$ (17.4 vs. 68.8 months, $p=0.011$; Figure 4C-4D; Table 2).

\section{Multivariate analysis}

To determine whether any of the analyzed variables had independent prognostic impact, a multivariate analysis was performed, where significant biomarker and clinicopathological variables from the univariate analyses were entered in the analysis. Multivariate models for gene expression markers and for the immune cell markers assessed by IHC were carried out separately due to the different number of patients analyzed, and results are summarized in Table 3. As for the multivariate model including gene expression markers, PFS was adjusted for tumor size, which was significanty associated with PFS in the univariate analysis. The expression of CD8 in the tumor compartment was found to be an independent beneficial prognostic factor for both PFS $(p<0.001)$ and OS $(p<0.001)$.

A second multivariate model including immune cells
TUMOR
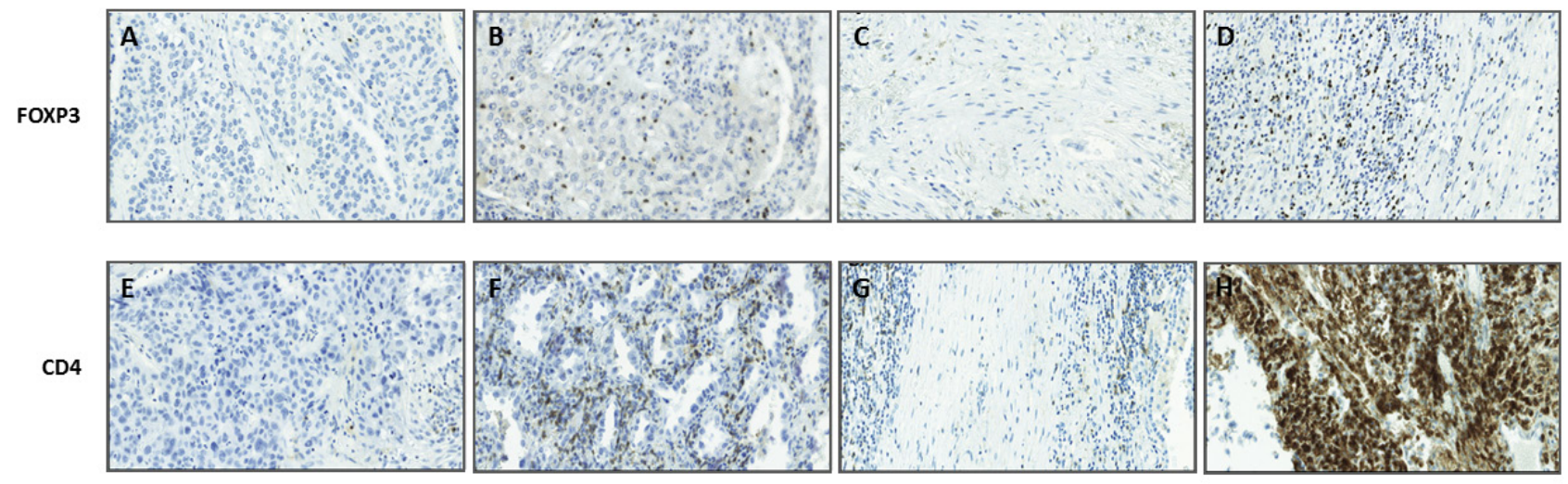

CD8

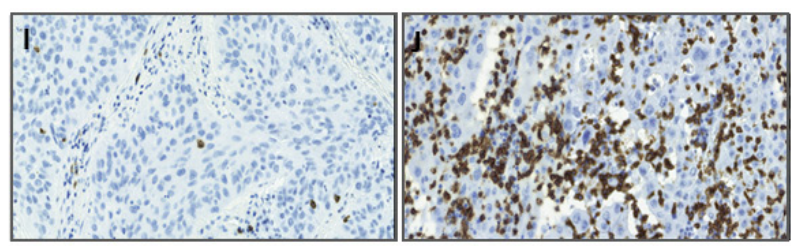

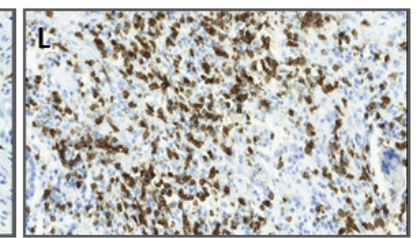

Figure 1: Representative immunohistochemical staining of FOXP3, CD4 and CD8 in tumor and stroma compartments. Original magnification X200. A. Low infiltration of FOXP3 ${ }^{+}$lymphocytes in tumor compartment, $\mathbf{B}$. high infiltration of FOXP3 $3^{+}$lymphocytes in tumor compartment, C. low infiltration of FOXP3 $3^{+}$lymphocytes in stroma compartment, D. high infiltration of FOXP3 ${ }^{+}$lymphocytes in stroma compartment, E. low infiltration of $\mathrm{CD}^{+}$lymphocytes in tumor compartment, $\mathbf{F}$. high infiltration of $\mathrm{CD}^{+}$lymphocytes in tumor compartment, G. low infiltration of $\mathrm{CD}^{+}$lymphocytes in stroma compartment and, H. high infiltration of CD4 $4^{+}$lymphocytes in stroma compartment, I. Low infiltration of $\mathrm{CD}^{+}$lymphocytes in tumor compartment, J. high infiltration of $\mathrm{CD} 8^{+}$lymphocytes in tumor compartment, K. low infiltration of $\mathrm{CD}^{+}$lymphocytes in stroma compartment, L. high infiltration of CD8 ${ }^{+}$lymphocytes in stroma compartment. 
markers determined by IHC was performed as well. In this model lymph node involvement and PS were included for both OS and PFS due to their significant correlation with survival observed in the univariate analysis. Here, results indicated that the presence of $\mathrm{CD} 8+$ cells in the tumor compartment and FOXP3+ cells in the stromal compartment, were independent prognostic biomarkers for OS ( $p=0.018$ and $p=0.024$, respectively), and CD8+ cell infiltration in the tumor compartment was an independent prognostic factor also for PFS $(p=0.004)$.

\section{a)}

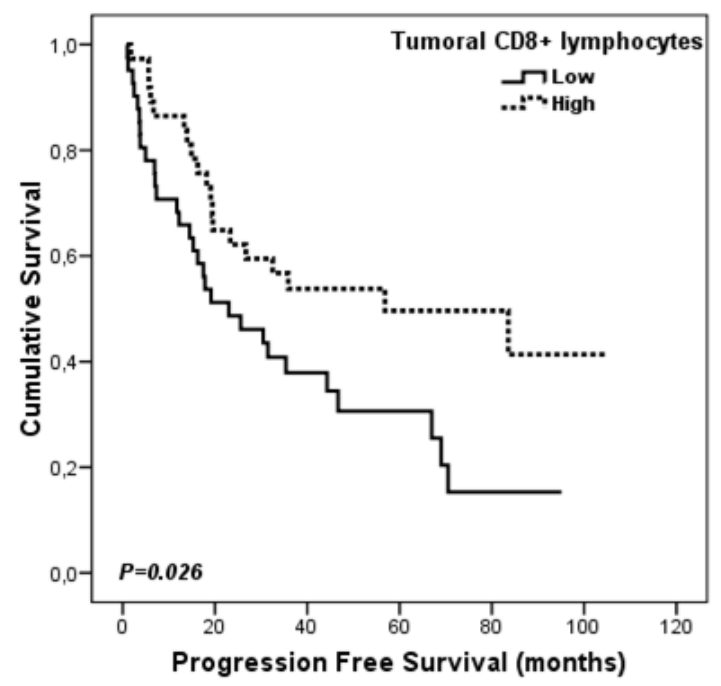

c)

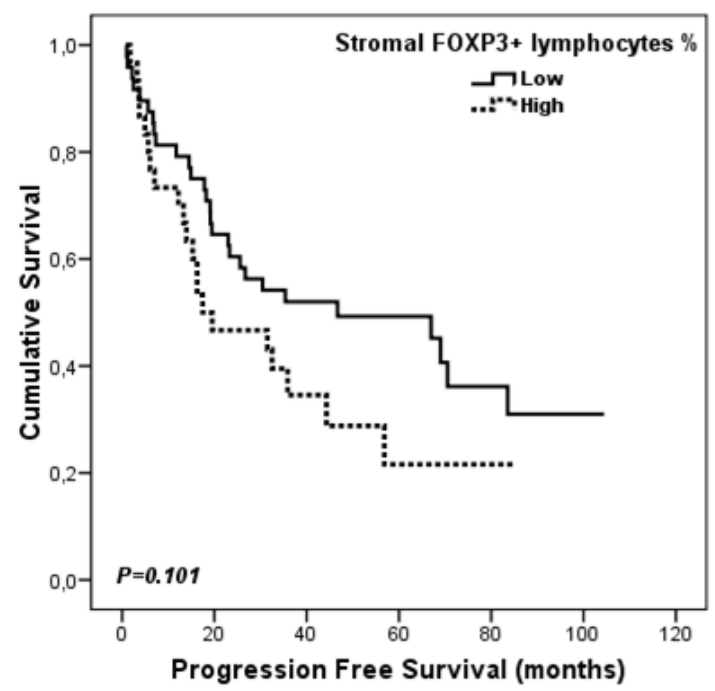

\section{DISCUSSION}

Over the past decade, the field of tumor immunology has been increasingly investigated. Today, it is generally accepted that the immune system plays a pivotal role in cancer, and provides prognostic and predictive markers. In our study, we have found that gene expression levels of CD8 in both tumor and tumor-near stroma compartments, and of CD4 only in the tumor compartment, were correlated with better outcomes. Furthermore, when the infiltration of cells positive for these markers was assessed

b)

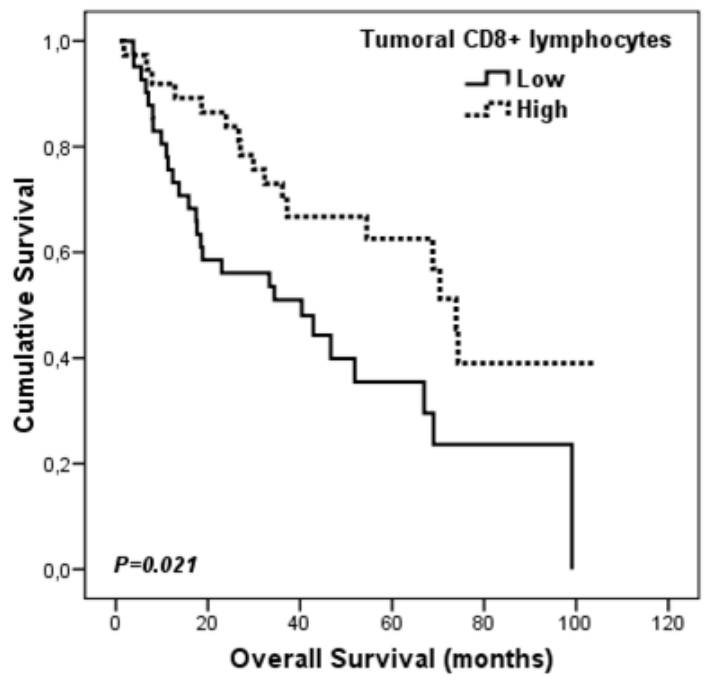

d)

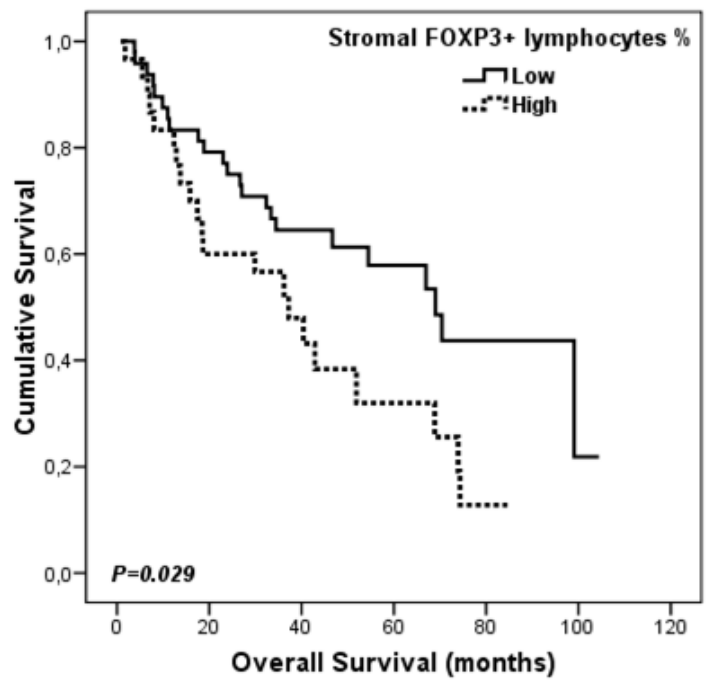

Figure 2: Kaplan-Meier plots for progression free survival and overall survival according to immune cells infiltration. A., B. Infiltration of $\mathrm{CD}^{+}$cells in tumor compartment and, C., D. infiltration of FOXP3 ${ }^{+}$cells in the stroma compartment. Densities were dichotomized as high and low infiltration according to the median of positive lymphocytes.. 
by IHC, only the presence of CD8+ cells in the tumor compartment was correlated with survival.

Although TILs have been widely assessed in the tumor microenvironment by IHC, little has been published regarding the expression of TIL-associated genes at the mRNA level. The latter approach is challenging because while it is highly feasible to distinguish between tumor versus stromal compartments by microscopy (IHC), this is more demanding when using RTqPCR, despite carefully performed tissue microdissections. On the other hand, the RTqPCR methods are more sensitive and

\section{a)}

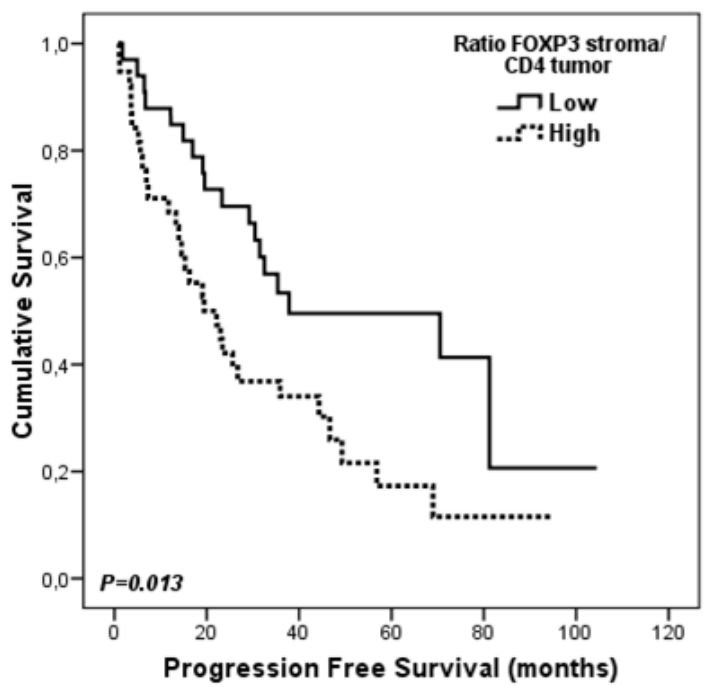

c)

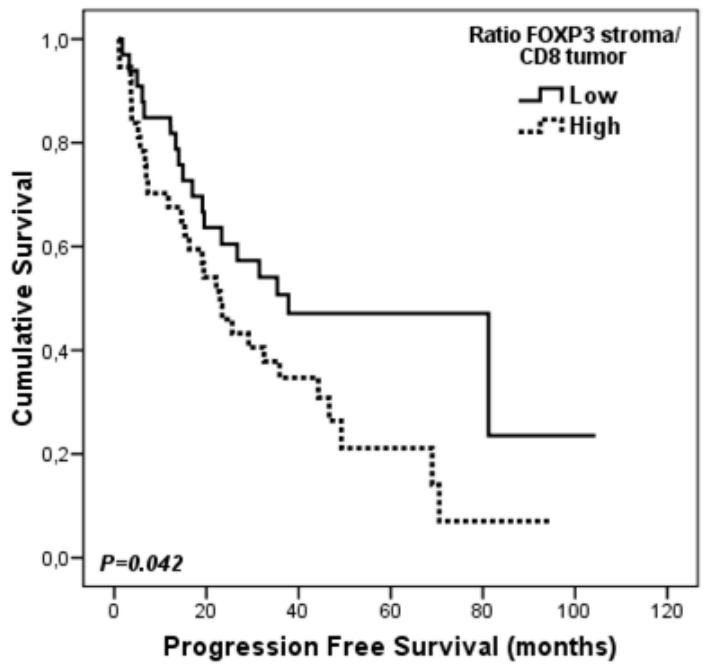

objective, whereas IHC data are semiquantitative with the inconvenience that it may infer.

Among TILs, CD8+ cells form the effector arm of adaptive immunity with cytotoxic activity and are considered to have tumor preventive effects. We have observed that the presence of CD8+ cells in the tumor compartment, detected either by IHC or by RTqPCR, is highly associated with a beneficial prognosis. Accordingly, Ruffini et al. observed that CD8+ cells were associated with prolonged survival in 1290 stage I-IIIA NSCLC patients, but that an independent prognostic impact was

b)

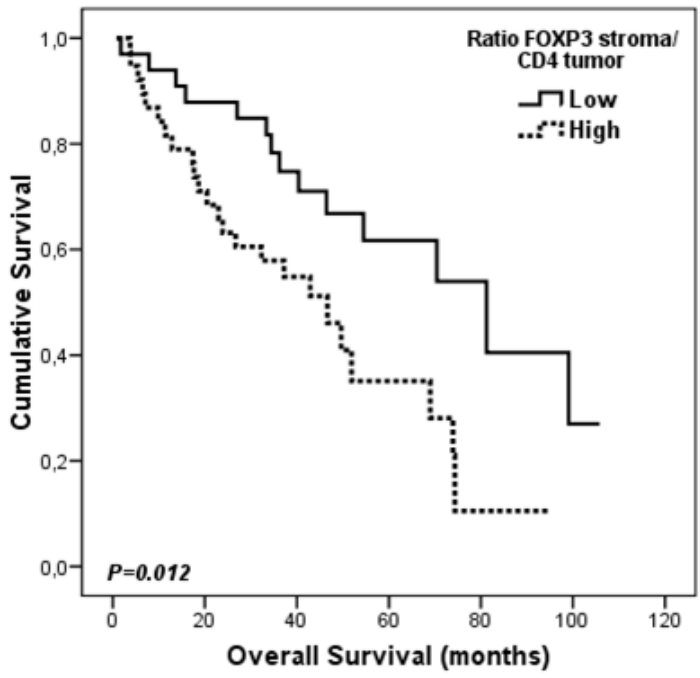

d)

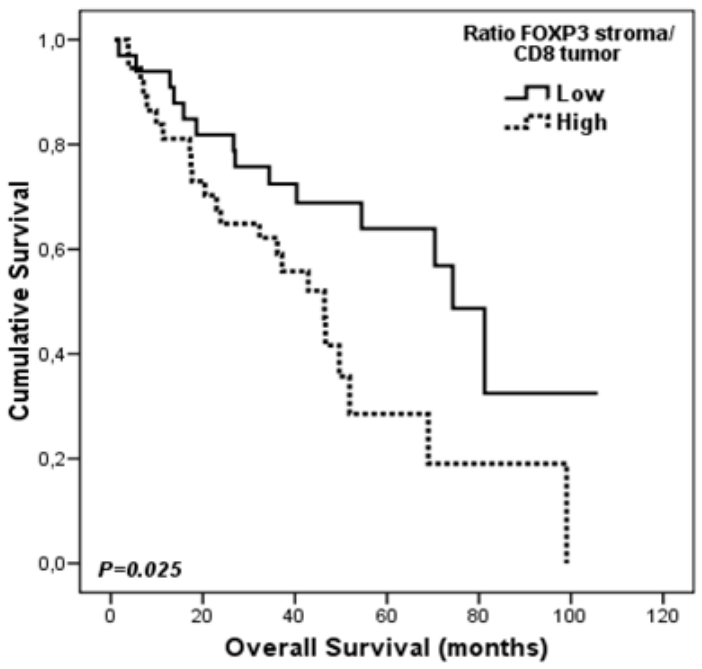

Figure 3: Kaplan-Meier plots for progression free survival and overall survival according to the ratios for conventional and regulatory gene expression markers. A., B. FOXP3 stroma/ CD4 tumor expression ratio and, C., D. FOXP3 stroma/ CD8 tumor expression ratio. Gene expression levels were dichotomized according to the median. 
associated with squamous cell carcinomas only [30]. At about the same time Al-Shibli et al. observed that high CD8+ lymphocyte infiltration, in both tumor and stromal areas, was associated with better survival in 335 resected stage I-IIIA NSCLC patients [10]. Recently, it has been demonstrated that the density of stromal CD8+ cells, due to its significant independent prognostic impact, might be a good candidate marker for establishing a TNMImmunoscore in resected NSCLC [11].

In contrast, the presence of CD4+ cells in different types of cancer [31-33] has yielded contradictory results

\section{a)}

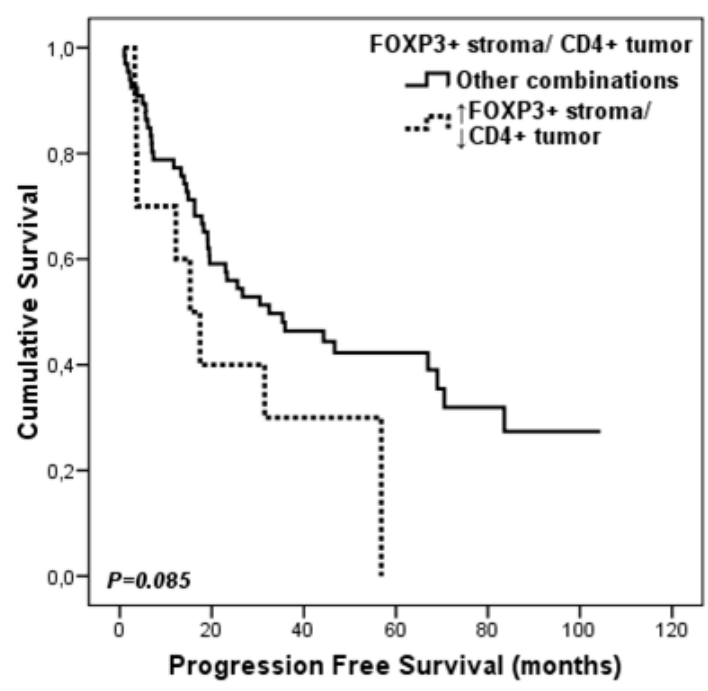

c)

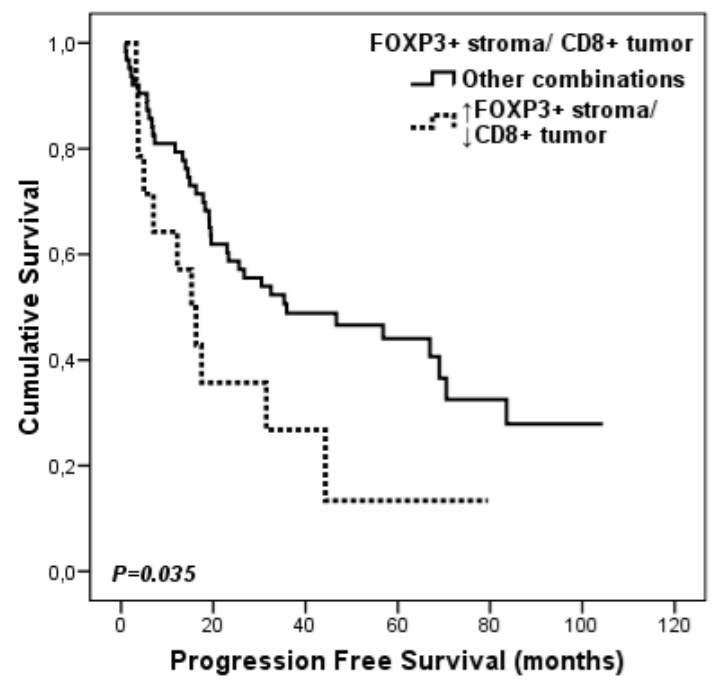

regarding prognosis. In lung tumors, the presence of stromal CD4+ lymphocytes has, in general, been correlated with improved survival $[10,34,35]$. Our results obtained by IHC are consistent with previous NSCLC studies. In a 50-gene signature study of stage I/II NSCLC tumors the presence of CD4+ cells did not correlate with survival [36]. This discrepancy can be explained by the fact that CD4+ TILs form a heterogeneous population of cells with different phenotypes and even with opposing actions in the tumor microenvironment [9].

In our study, FOXP3+ provided opposite results

b)

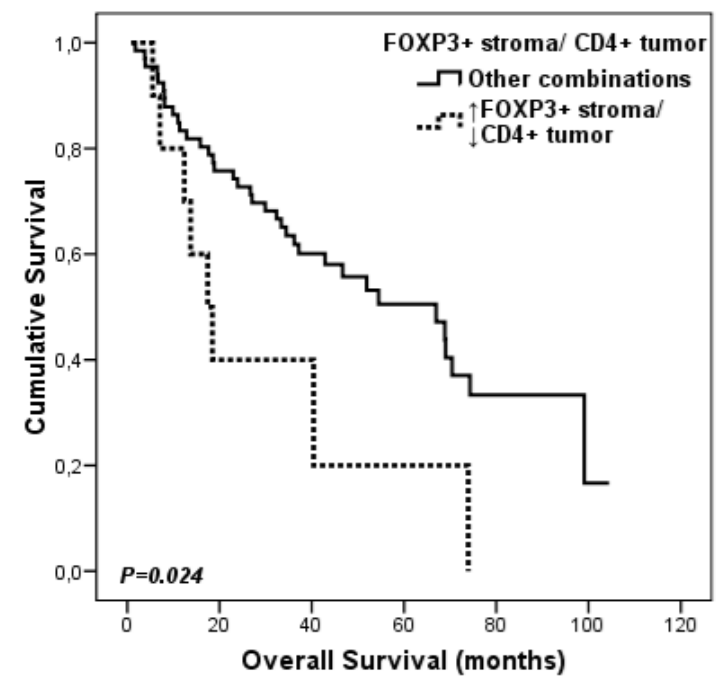

d)

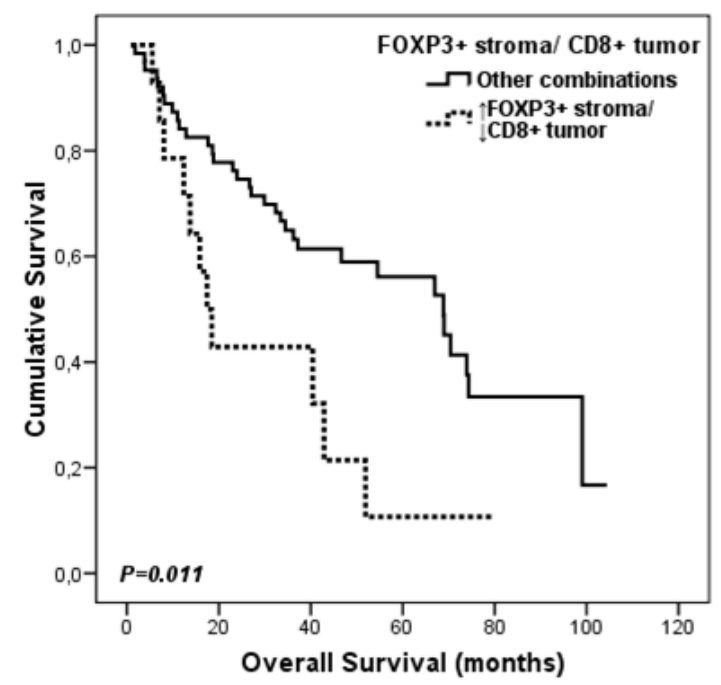

Figure 4: Kaplan-Meier plots for progression free survival and overall survival according to the FOXP3 ${ }^{+}$cells proportion to conventional $\mathbf{T}$ cells markers. A., B. Combination of FOXP3 ${ }^{+}$cells in the stroma/CD4 $4^{+}$cells in the tumor, and $\mathbf{C}$., D. combination of $\mathrm{FOXP}^{+}$cells in the stroma/ $\mathrm{CD} 8^{+}$cells in the tumor. 
according to compartment analyzed and methodology. While FOXP3 gene expression levels in the tumor were significantly associated with better outcomes, the presence of FOXP3 + cells in the stroma had the opposite effect. In previous studies with different types of cancer, the presence of FOXP3 + cells has been associated with both poor [37, 38] and improved OS [39-41], although mRNA expression levels were not assessed in any of these studies. A possible explanation for this observation is the extreme heterogeneity of resected carcinomas, the mixed patterns of adenocarcinomas [42], and the fact that we could not select areas representative of all the major tissue patterns present. Additionally, cancer cells positive for FOXP3 have been detected in several distinct types of cancer $[37,43]$ that could attenuate the unfavorable prognostic influence of the tumor-infiltrating Tregs detected by IHC. In contrast, the presence of FOXP3+ cells or Tregs in the stroma was correlated with worse survival. Shimizu et al. demonstrated that patients with NSCLC (stages I-IIIB) containing three or more infiltrating Treg cells/10 HPFs in the tumor tissue had significantly worse recurrence-free survival (RFS), and among patients with node-negative NSCLC, Tregs were an independent poor prognostic factor [38]. An increased Treg count was also found to be associated with worse OS and RFS in another study with I-IIIA stage NSCLC [37]. Furthermore, a high density of stromal FOXP3+ cells was associated with a shorter recurrence-free probability [44]. Another possible explanation for this results may come from the heterogeneous phenotypes described for FOXP3+ regulatory $\mathrm{T}$ lymphocytes [45], their epigenetic regulation [46] or the presence of exhausted phenotypes [47]. Our results indicate that there is a great variability of each particular subpopulation between patients and this aspect could affect to the designation of a potential biomarker. This variability can be explained because immune cells are more prone to be located in the stroma than within the tumor compartment. As for the difference between the particular subpopulations, it was expected to obtained similar data for CD4 and CD8 positive cells, but not in the FOXP3 positive cells case. This is due to the fact that FOXP3 cells or regulatory $\mathrm{T}$ cells are less common than conventional $\mathrm{T}$ cell. All these observations emphasize the importance of assessing the location and type of immune cells within the tumor microenvironment.

Our data shows that patients with high expression levels of LAG3 in the tumor compartment presented a better outcome. LAG3 functions as an immune checkpoint and has a role in enhancing the function of Treg cells [48]. To the best of our knowledge, the prognostic value of LAG3 has not previously been assessed in NSCLC or any other tumor type. Another marker that presented a significant association with OS when expressed in the tumor compartment was TGFB1. This marker plays a critical and dual role in the progression of human cancer [49-52] and in NSCLC a recently published work reported that TGFB1 positive patients showed remarkably longer survival than the others [53].

We also studied the prognostic value of conventional TILs such as CD4+ and CD8+ cells in combination with FOXP3+ cells. In addition to type, density, and location, we have also demonstrated that the relative proportion of pro- and antitumor immune cells should be studied when analyzing TILs. According to our data, the ratio of FOXP3+ vs CD4+ or CD8+ cells in both the tumor and stromal compartment had a prognostic value. In this regard, it was observed that patients with stage I NSCLC with a higher proportion of tumor Tregs relative to CD3+ TILs, a pan-T cell marker that does not differentiate among helper and cytotoxic $\mathrm{T}$ cells, had a significantly higher risk of recurrence [54]. In a previous study including stage I adenocarcinomas, tumors containing high stromal FOXP3 + and low stromal CD3+ were considered to be more progressive, and FOXP3+ high versus stromal CD3+ low was found to be a strong predictor of recurrence [44]. To the best of our knowledge, our study is the first reporting the prognostic value of Tregs versus cytotoxic or helper TILs in the tumor or tumor-near stromal compartment.

In the multivariate analysis, CD8 gene expression by means of RTqPCR and infiltrating CD8+ cells evaluated by IHC in the tumor compartment were found to be independent prognostic factors for OS and PFS, probably indicating an ongoing immune response against the tumor [55]. Furthermore, FOXP3+ cells in the tumornear stroma compartment was an independent negative prognostic factor for OS, emphasizing the importance of assessing the location of immune cells within the tumor microenvironment.

In conclusion, although some papers address the role in CD8 and Foxp3 in lung cancer, the original aspects of this study lies in the fact that the tumor and stroma compartment of the tumor tissue have been investigated separately with a double approach using IHC and RTqPCR. Thus, the presence of CD8+ TILs in the tumor compartment, both at mRNA level and detected by IHC, identified a group of patients with longer survival, suggesting that an activated immune response might have an important role in patient outcome. In contrast, the presence of FOXP3 + cells in the stromal compartment identified a subset of patients with worse survival. This association was also specifically observed when the density of CD8+ and CD4+ in the tumor was low, but not in other cases, suggesting the importance of assessing the relative proportion of conventional and regulatory $\mathrm{T}$ cells present in the tumor surroundings. Further investigations and prospective clinical studies will be required to validate these results and their possible therapeutic implications. 


\section{MATERIALS AND METHODS}

\section{Patients and tissue samples}

In this retrospective study, 122 patients from Consorcio Hospital General Universitario de Valencia with a clinical and histological diagnosis of stage I to IIIA (according to the American Joint Committee on Cancer staging manual) NSCLC and diagnosed between 2004 and 2013, were included. None of the patients received chemoor radiotherapy prior to surgery. The study was conducted in accordance with the Declaration of Helsinki, and the institutional ethical review board approved the protocol. Reported recommendations for tumor marker prognostic studies (REMARK) criteria were followed throughout the study [56]. Progression-free survival (PFS) was estimated as the time from surgery to recurrence or death from the disease, whereas overall survival (OS) was defined as the time from diagnosis to the date of death or last follow up. Formalin-fixed, paraffin-embedded (FFPE) samples obtained from tumor resections in these patients were used in this study.

\section{Gene expression analysis}

Laser capture microdissection was performed in order to separately collect tumor and tumor-near stroma tissue areas from 122 FFPE tumor specimens. For this purpose, a LMD6500 Leica laser microdissection system (Leica, Wetzlar, Germany) was used with the support of a Hitachi HV-D20 camera (Hitachi Kokusai Electric, Tokyo, Japan). RNA was isolated using a RecoverAll ${ }^{\mathrm{TM}}$ Total Nucleic Acid Isolation Kit (Ambion, Austin, TX, USA) following the manufacturer's recommendations. Reverse transcription (RT) reactions were performed from $100 \mathrm{ng}$ of total RNA using random hexanucleotides and a High-Capacity cDNA Reverse Transcription Kit (Applied Biosystems, Foster City, CA, USA) following the manufacturer's instructions. The thermal cycling conditions were as follows: $10 \mathrm{~min}$ at $25^{\circ} \mathrm{C}, 120 \mathrm{~min}$ at $37^{\circ} \mathrm{C}$, and $5 \mathrm{~s}$ at $85^{\circ} \mathrm{C}$. A TaqMan ${ }^{\circledR}$ PreAmp Master Mix Kit (Applied Biosystems) was used for preamplification to increase the quantity of specific cDNA target. The preamplification conditions were as follows: $10 \mathrm{~min}$ at $95^{\circ}$ $\mathrm{C}$ for enzyme activation, followed by 10 cycles of $15 \mathrm{~s}$ at $95^{\circ} \mathrm{C}$ and, finally, $4 \mathrm{~min}$ at $60^{\circ} \mathrm{C}$.

RTqPCR was performed to analyze the relative expression of $C D 4, C D 8, F O X P 3, C D 25, C D 127, C T L A 4$, $L A G 3$, GITR, TGFBI and ILI0 genes with assays based on hydrolysis probes using $1 \mu \mathrm{l}$ of cDNA, a Universal Master Mix, and a TaqMan Gene Expression Assay (Applied Biosystems), in a $5 \mu \mathrm{l}$ final reaction volume. GAPDH and $C D K N 1 B$ were selected as endogenous controls by using the GeNorm algorithm. The thermal cycling parameters were as follows: $2 \mathrm{~min}$ at $50^{\circ} \mathrm{C}$ and $10 \mathrm{~min}$ at $95^{\circ} \mathrm{C}$ followed by 40 cycles of $15 \mathrm{~s}$ at $95^{\circ} \mathrm{C}$ and $1 \mathrm{~min}$ at $60^{\circ} \mathrm{C}$. For efficiency calculations, we used random-primed qPCR Human Reference cDNA (Clontech, USA). Relative gene expression levels were expressed as the ratio of target gene expression to the geometric mean of the endogenous gene expression by using the Pfaffl formula [57]. We considered a gene to be overexpressed in the tumor or tumor-near stroma compartment when the median of the relative gene expression referred to the human cDNA was higher than 2 and underexpressed when it was less than 0.5. Gene expression levels were dichotomized as "high" and "low" according to the median of each case.

\section{Immunohistochemistry}

In this study, the expression of FOXP3, CD4, and CD8 was evaluated in 84 of the FFPE samples included using a Dako Autostainer Link 48 and the Dako EnVision ${ }^{\text {TM }}$ FLEX detection system (Dako, Burlington, Canada). Briefly, sections were dried and loaded into the PT Link instrument where the antigen retrieval/dewaxing process took place. The sections were transferred to the Autostainer Link 48 instrument where the endogenous peroxidase activity was quenched with peroxidase blocking reagent for 10 minutes. Immunostaining was carried out with Dako FLEX Ready to-Use format for CD4 (Clone 4B12, Dako) and CD8 (Clone C8/144B, Dako), and with a primary antibody diluted at 1:300 with Dako Antibody Diluent (Dako) for FOXP3 (Clone 236A/ E7, Abcam, Cambridge, MA, USA). After incubation with the primary antibody a detection system chromogen (3,3'-diaminobenzidine, DAB) was used. Finally, the sections were washed, lightly counterstained with hematoxilin, dehydrated, and mounted. Normal human tonsil tissue was used as a positive control for the three antibodies, and negative controls were included by omitting the primary antibody.

\section{Quantification of immunohistochemical staining}

The slides were independently examined by two researchers ( $\mathrm{SC}, \mathrm{JF}$ or $\mathrm{MM}$ ), all were blinded to cases and data. Before initiating the scoring, controls were reviewed for quality assurance, compartments for scoring were agreed upon and the semiquantitative scale to be used was defined. To evaluate FOXP3 immunostaining, the percentage of nuclear-stained lymphocytes present in the tumor and tumor-near stroma was defined and graded on a scale of 0-3 according to the percentage of positive lymphocyte cells: $0=$ no staining, $1=$ less than $10 \%$ positive, $2=10-32 \%$ positive, $3=33 \%$ or more positive. Furthermore, high power fields (HPFs; magnification $\mathrm{X} 400$ ) were analyzed in 10 tumor or stromal areas per sample and the absolute number of FOXP3+ lymphocytes 
was determined and then averaged. CD4+ and CD8+ lymphocytes were also counted in $10 \mathrm{HPFs}$ for both tumor and tumor-near stroma areas, and were then averaged. We used $10 \%$ positive lymphocytes as a low-high cutoff value for FOXP3+ cell dichotomization. High power fields (HPFs; magnification X400) were analyzed in 10 tumor or stromal areas per sample and the absolute number of CD4+ and CD8+ cells was determined, and the median was obtained in each case. The median of positive cells was used as a cutoff in both cases. Examples of IHC images representing different infiltration scores in tumor and tumor-near stroma locations are shown in Figure 1.

\section{Statistical analysis}

Continuous variables were compared by nonparametric Mann-Whitney U and Kruskall-Wallis tests. A Spearman rank test was used to test for correlations between continuous variables. Correlated variables were not included in the same multivariate model and the association between dichotomized variables was evaluated by the Chi-square test. Survival analysis was performed using a univariate Kaplan-Meier (log-rank) test method with clinicopathological variables, dichotomized gene expression marker levels, and density of immune cell infiltration levels. Finally, to assess the independent value of the tested biomarkers, a Cox proportional hazard model for multivariate analyses was used. All significant variables from the univariate analyses were entered into the multivariate analyses in a forward stepwise Cox regression analysis. A probability of $95 \%(P<0.05)$ was considered statistically significant for all analyses. The statistical analyses were done using the Statistical Package for the Social Sciences (SPSS, Chicago, IL, USA) version 15.0 .

\section{CONFLICTS OF INTEREST}

The authors declare no conflict of interest.

\section{GRANT SUPPORT}

This work was supported by the Red Temática de Investigación Cooperativa en Cáncer (RD12/0036/0025) and the Fondo de Investigación Sanitaria-Fondo Europeo de Desarrollo Regional (PI09/01147, PI09/01149 and PI12/02838).

\section{REFERENCES}

1. Jemal A, Bray F, Center MM, Ferlay J, Ward E, Forman D. Global cancer statistics. CA Cancer J Clin. 2011;61:69-90.

2. Goldstraw P, Ball D, Jett JR, Le Chevalier T, Lim E, Nicholson AG, Shepherd FA. Non-small-cell lung cancer. Lancet (London, England). 2011;378:1727-1740.
3. Burotto M, Thomas A, Subramaniam D, Giaccone G, Rajan A. Biomarkers in early-stage non-small-cell lung cancer: current concepts and future directions. J Thorac Oncol. 2014;9:1609-1617.

4. Camps C, Jantus-Lewintre E, Cabrera A, Blasco A, Sanmartín E, Gallach S, Caballero C, del Pozo N, Rosell R, Guijarro R, Sirera R. The identification of KRAS mutations at codon 12 in plasma DNA is not a prognostic factor in advanced non-small cell lung cancer patients. Lung Cancer. 2011;72:365-369.

5. Zhang L, Conejo-Garcia JR, Katsaros D, Gimotty PA, Massobrio M, Regnani G, Makrigiannakis A, Gray H, Schlienger K, Liebman MN, Rubin SC, Coukos G. Intratumoral $\mathrm{T}$ cells, recurrence, and survival in epithelial ovarian cancer. N Engl J Med. 2003;348:203-213.

6. Mahmoud SMA, Paish EC, Powe DG, Macmillan RD, Grainge MJ, Lee AHS, Ellis IO, Green AR. Tumorinfiltrating CD8+ lymphocytes predict clinical outcome in breast cancer. J Clin Oncol. 2011;29:1949-1955.

7. Mlecnik B, Tosolini M, Kirilovsky A, Berger A, Bindea G, Meatchi T, Bruneval P, Trajanoski Z, Fridman W-H, Pagès F, Galon J. Histopathologic-based prognostic factors of colorectal cancers are associated with the state of the local immune reaction. J Clin Oncol. 2011;29:610-618.

8. Bremnes RM, Sirera R, Al-saad S, Camps C, Busund L. The Role of Tumor-Infiltrating Immune Cells and Chronic Inflammation at the Tumor Site on Cancer Development, Progression, and Prognosis. J Thorac Oncol. 2011;6:1-10.

9. Fridman WH, Pagès F, Sautès-Fridman C, Galon J. The immune contexture in human tumours: impact on clinical outcome. Nat Rev Cancer. 2012;12:298-306.

10. Al-Shibli KI, Donnem T, Al-Saad S, Persson M, Bremnes RM, Busund L-T. Prognostic effect of epithelial and stromal lymphocyte infiltration in non-small cell lung cancer. Clin Cancer Res. 2008;14:5220-5227.

11. Donnem T, Hald SM, Paulsen E-E, Richardsen E, Al-Saad S, Kilvaer TK, Brustugun OT, Helland A, Lund-Iversen M, Poehl M, Olsen KE, Ditzel HJ, Hansen O, et al. Stromal CD8+ T-cell Density - A Promising Supplement to TNM Staging in Non-Small Cell Lung Cancer. Clin Cancer Res. 2015;21:2635-2643.

12. Donnem T, Kilvaer TK, Andersen S, Richardsen E, Paulsen E, Hald SM, Al-Saad S, Brustugun OT, Helland A, Lund-Iversen M, Solberg S, Gronberg BH, Wahl SGF, et al. Strategies for clinical implementation of TNMimmunoscore in resected non-small cell lung cancer. Ann Oncol. 2015:1-8.

13. Hiraoka K, Miyamoto M, Cho Y, Suzuoki M, Oshikiri T, Nakakubo Y, Itoh T, Ohbuchi T, Kondo S, Katoh H. Concurrent infiltration by CD8 $+\mathrm{T}$ cells and CD4+ T cells is a favourable prognostic factor in non-small-cell lung carcinoma. Br J Cancer. 2006;94:275-280.

14. Alifano M, Mansuet-Lupo A, Lococo F, Roche N, Bobbio A, Canny E, Schussler O, Dermine H, Régnard J-F, Burroni 
B, Goc J, Biton J, Ouakrim H, et al. Systemic inflammation, nutritional status and tumor immune microenvironment determine outcome of resected non-small cell lung cancer. PLoS One. 2014;9:e106914.

15. Schalper KA, Brown J, Carvajal-Hausdorf D, McLaughlin J, Velcheti V, Syrigos KN, Herbst RS, Rimm DL. Objective measurement and clinical significance of TILs in non-small cell lung cancer. J Natl Cancer Inst. 2015;107.

16. Koh J, Go H, Keam B, Kim M-Y, Nam SJ, Kim TM, Lee S-H, Min HS, Kim YT, Kim D-W, Jeon YK, Chung DH. Clinicopathologic analysis of programmed cell death-1 and programmed cell death-ligand 1 and 2 expressions in pulmonary adenocarcinoma: comparison with histology and driver oncogenic alteration status. Mod Pathol. 2015;28:1154-1166.

17. Seddiki N, Santner-Nanan B, Martinson J, Zaunders J, Sasson S, Landay A, Solomon M, Selby W, Alexander SI, Nanan R, Kelleher A, Fazekas de St Groth B. Expression of interleukin (IL)-2 and IL-7 receptors discriminates between human regulatory and activated T cells. J Exp Med. 2006;203:1693-1700.

18. Sakaguchi S, Yamaguchi T, Nomura T, Ono M. Regulatory T cells and immune tolerance. Cell. 2008;133:775-787.

19. Zheng Y, Josefowicz SZ, Kas A, Chu T-T, Gavin MA, Rudensky AY. Genome-wide analysis of Foxp3 target genes in developing and mature regulatory T cells. Nature. 2007;445:936-940.

20. Vignali DAA, Collison LW, Workman CJ. How regulatory T cells work. Nat Rev Immunol. 2008;8:523-532.

21. Curiel TJ, Coukos G, Zou L, Alvarez X, Cheng P, Mottram P, Evdemon-Hogan M, Conejo-Garcia JR, Zhang L, Burow M, Zhu Y, Wei S, Kryczek I, et al. Specific recruitment of regulatory $\mathrm{T}$ cells in ovarian carcinoma fosters immune privilege and predicts reduced survival. Nat Med. 2004;10:942-949.

22. Bates GJ, Fox SB, Han C, Leek RD, Garcia JF, Harris AL, Banham AH. Quantification of Regulatory T Cells Enables the Identification of High-Risk Breast Cancer Patients and Those at Risk of Late Relapse. J Clin Oncol. 2006;24:53735380 .

23. Griffiths RW, Elkord E, Gilham DE, Ramani V, Clarke N, Stern PL, Hawkins RE. Frequency of regulatory $T$ cells in renal cell carcinoma patients and investigation of correlation with survival. Cancer Immunol Immunother. 2007;56:1743-1753.

24. Hiraoka N, Onozato K, Kosuge T, Hirohashi S. Prevalence of FOXP3+ regulatory $\mathrm{T}$ cells increases during the progression of pancreatic ductal adenocarcinoma and its premalignant lesions. Clin Cancer Res. 2006;12:5423-5434.

25. Perrone G, Ruffini PA, Catalano V, Spino C, Santini D, Muretto P, Spoto C, Zingaretti C, Sisti V, Alessandroni P, Giordani P, Cicetti A, D'Emidio S, et al. Intratumoural FOXP3-positive regulatory $\mathrm{T}$ cells are associated with adverse prognosis in radically resected gastric cancer. Eur $\mathrm{J}$
Cancer. 2008;44:1875-1882.

26. Badoual C, Hans S, Rodriguez J, Peyrard S, Klein C, Agueznay NEH, Mosseri V, Laccourreye O, Bruneval P, Fridman WH, Brasnu DF, Tartour E. Prognostic value of tumor-infiltrating CD4+ T-cell subpopulations in head and neck cancers. Clin Cancer Res. 2006;12:465-472.

27. Bron L, Jandus C, Andrejevic-Blant S, Speiser DE, Monnier P, Romero P, Rivals J-P. Prognostic value of arginase-II expression and regulatory $\mathrm{T}$-cell infiltration in head and neck squamous cell carcinoma. Int J Cancer. 2013;132:E85-E93.

28. Salama P, Phillips M, Grieu F, Morris M, Zeps N, Joseph D, Platell C, Iacopetta B. Tumor-infiltrating FOXP3+ T regulatory cells show strong prognostic significance in colorectal cancer. J Clin Oncol. 2009;27:186-192.

29. Winerdal ME, Marits P, Winerdal M, Hasan M, Rosenblatt R, Tolf A, Selling K, Sherif A, Winqvist O. FOXP3 and survival in urinary bladder cancer. BJU Int. 2011;108:16721678.

30. Ruffini E, Asioli S, Filosso PL, Lyberis P, Bruna MC, Macrì L, Daniele L, Oliaro A. Clinical significance of tumorinfiltrating lymphocytes in lung neoplasms. Ann Thorac Surg. 2009;87:365-371; discussion 371-372.

31. Fukunaga A, Miyamoto M, Cho Y, Murakami S, Kawarada Y, Oshikiri T, Kato K, Kurokawa T, Suzuoki M, Nakakubo Y, Hiraoka K, Itoh T, Morikawa T, et al. CD8+ tumorinfiltrating lymphocytes together with CD4+ tumorinfiltrating lymphocytes and dendritic cells improve the prognosis of patients with pancreatic adenocarcinoma. Pancreas. 2004;28:e26-e31.

32. Cho Y, Miyamoto M, Kato K, Fukunaga A, Shichinohe T, Kawarada Y, Hida Y, Oshikiri T, Kurokawa T, Suzuoki M, Nakakubo Y, Hiraoka K, Murakami S, et al. CD4+ and CD8+ T Cells Cooperate to Improve Prognosis of Patients with Esophageal Squamous Cell Carcinoma. Cancer Res. 2003;63:1555-1559.

33. Bromwich EJ, McArdle PA, Canna K, McMillan DC, McNicol A-M, Brown M, Aitchison M. The relationship between T-lymphocyte infiltration, stage, tumour grade and survival in patients undergoing curative surgery for renal cell cancer. Br J Cancer. 2003;89:1906-1908.

34. Wakabayashi O, Yamazaki K, Oizumi S, Hommura F, Kinoshita I, Ogura S, Dosaka-Akita H, Nishimura M. $\mathrm{CD} 4(+) \mathrm{T}$ cells in cancer stroma, not CD8(+) $\mathrm{T}$ cells in cancer cell nests, are associated with favorable prognosis in human non-small cell lung cancers. Cancer Sci. 2003;94:1003-1009.

35. Hald SM, Bremnes RM, Al-Shibli K, Al-Saad S, Andersen $\mathrm{S}$, Stenvold H, Busund L-T, Donnem T. CD4/CD8 coexpression shows independent prognostic impact in resected non-small cell lung cancer patients treated with adjuvant radiotherapy. Lung Cancer. 2013;80:209-215.

36. Hernández-Prieto S, Romera a., Ferrer M, Subiza JL, López-Asenjo J a., Jarabo JR, Gómez a. M, Molina EM, 
Puente J, González-Larriba JL, Hernando F, Pérez-Villamil B, Díaz-Rubio E, et al. A 50-gene signature is a novel scoring system for tumor-infiltrating immune cells with strong correlation with clinical outcome of stage I/II nonsmall cell lung cancer. Clin Transl Oncol. 2014; 17:330-338.

37. Tao H, Mimura Y, Aoe K, Kobayashi S, Yamamoto H, Matsuda E, Okabe K, Matsumoto T, Sugi K, Ueoka H. Prognostic potential of FOXP3 expression in non-small cell lung cancer cells combined with tumor-infiltrating regulatory T cells. Lung Cancer. 2012;75:95-101.

38. Shimizu K, Nakata M, Hirami Y, Yukawa T, Maeda A, Tanemoto K. Tumor-infiltrating Foxp3+ regulatory T cells are correlated with cyclooxygenase- 2 expression and are associated with recurrence in resected non-small cell lung cancer. J Thorac Oncol. 2010;5:585-590.

39. Ladoire S, Mignot G, Dalban C, Chevriaux A, Arnould L, Rébé C, Apetoh L, Boidot R, Penault-Llorca F, Fumoleau P, Roché H, Spielmann M, Levy C, et al. FOXP3 expression in cancer cells and anthracyclines efficacy in patients with primary breast cancer treated with adjuvant chemotherapy in the phase III UNICANCER-PACS 01 trial. Ann Oncol. 2012;23:2552-2561.

40. Huang Y, Liao H, Zhang Y, Yuan R, Wang F, Gao Y, Wang $\mathrm{P}, \mathrm{Du} \mathrm{Z}$. Prognostic value of tumor-infiltrating FoxP3+ T cells in gastrointestinal cancers: a meta analysis. PLoS One. 2014;9:e94376.

41. Ma G-F, Miao Q, Liu Y-M, Gao H, Lian J-J, Wang Y-N, Zeng X-Q, Luo T-C, Ma L-L, Shen Z-B, Sun Y-H, Chen $\mathrm{S}-\mathrm{Y}$. High FoxP3 expression in tumour cells predicts better survival in gastric cancer and its role in tumour microenvironment. Br J Cancer. 2014;110:1552-1560.

42. Sica G, Yoshizawa A, Sima CS, Azzoli CG, Downey RJ, Rusch VW, Travis WD, Moreira AL. A grading system of lung adenocarcinomas based on histologic pattern is predictive of disease recurrence in stage I tumors. Am J Surg Pathol. 2010;34:1155-1162.

43. Triulzi T, Tagliabue E, Balsari A, Casalini P. FOXP3 expression in tumor cells and implications for cancer progression. J Cell Physiol. 2013;228:30-35.

44. Suzuki K, Kadota K, Sima CS, Nitadori J, Rusch VW, Travis WD, Sadelain M, Adusumilli PS. Clinical impact of immune microenvironment in stage I lung adenocarcinoma: tumor interleukin-12 receptor $\beta 2$ (IL-12R $\beta 2$ ), IL-7R, and stromal FoxP3/CD3 ratio are independent predictors of recurrence. J Clin Oncol. 2013;31:490-498.

45. Zhuo C, Xu Y, Ying M, Li Q, Huang L, Li D, Cai S, Li B. FOXP3+ Tregs: heterogeneous phenotypes and conflicting impacts on survival outcomes in patients with colorectal cancer. Immunol Res. 2015;61:338-347.
46. Waight JD, Takai S, Marelli B, Qin G, Hance KW, Zhang D, Tighe R, Lan Y, Lo K-M, Sabzevari H, Hofmeister R, Wilson NS. Cutting edge: epigenetic regulation of Foxp3 defines a stable population of CD4+ regulatory $\mathrm{T}$ cells in tumors from mice and humans. J Immunol. 2015;194:878882.

47. deLeeuw RJ, Kroeger DR, Kost SE, Chang P-P, Webb JR, Nelson BH. CD25 identifies a subset of CD4+FoxP3- TIL that are exhausted yet prognostically favorable in human ovarian cancer. Cancer Immunol Res. 2015;3:245-253.

48. Pardoll DM. The blockade of immune checkpoints in cancer immunotherapy. Nat Rev Cancer. 2012;12:252-264.

49. Meulmeester E, Ten Dijke P. The dynamic roles of TGF- $\beta$ in cancer. J Pathol. 2011;223:205-218.

50. Valkov A, Sorbye SW, Kilvaer TK, Donnem T, Smeland E, Bremnes RM, Busund L-T. The prognostic impact of TGF- $\beta 1$, fascin, NF- $\kappa \mathrm{B}$ and $\mathrm{PKC}-\zeta$ expression in soft tissue sarcomas. PLoS One. 2011;6:e17507.

51. Ciftci R, Tas F, Yasasever CT, Aksit E, Karabulut S, Sen F, Keskin S, Kilic L, Yildiz I, Bozbey HU, Duranyildiz D, Vatansever S. High serum transforming growth factor beta 1 (TGFB1) level predicts better survival in breast cancer. Tumour Biol. 2014;35:6941-6948.

52. Zhao L, Ji W, Zhang L, Ou G, Feng Q, Zhou Z, Lei M, Yang W, Wang L. Changes of circulating transforming growth factor-beta1 level during radiation therapy are correlated with the prognosis of locally advanced non-small cell lung cancer. J Thorac Oncol. 2010;5:521-525.

53. Gao Y, Wang Y, Sun L, Meng Q, Cai L, Dong X. Expression of TGF $\beta-1$ and EHD1 correlated with survival of non-small cell lung cancer. Tumour Biol. 2014;35:93719380.

54. Petersen RP, Campa MJ, Sperlazza J, Conlon D, Joshi M-B, Harpole DH, Patz EF. Tumor infiltrating Foxp3+ regulatory $\mathrm{T}$-cells are associated with recurrence in pathologic stage I NSCLC patients. Cancer. 2006;107:2866-2872.

55. Bui JD, Schreiber RD. Cancer immunosurveillance, immunoediting and inflammation: independent or interdependent processes? Curr Opin Immunol. 2007;19:203-208.

56. Altman DG, McShane LM, Sauerbrei W, Taube SE. Reporting recommendations for tumor marker prognostic studies (REMARK): explanation and elaboration. BMC Med. 2012;10:51.

57. Pfaffl MW. A new mathematical model for relative quantification in real-time RT-PCR. Nucleic Acids Res. 2001;29:e45. 